ЕНЕРГЕТИКА. ТЕПЛОТЕХНІКА.

ЕЛЕКТРОТЕХНІКА

UDC 662.767+662.614

O.I. Brunetkin, Ph.D., Assoc. Prof., S.O. Gorban

Odessa National Polytechnic University, 1 Shevchenko Ave., Odessa, Ukraine. 65044; e-mail: brunetkin@opu.ua

\title{
HEAT TRANSFER OPTIMIZATION OF HEAT EXCHANGE SURFACES OF BOILER EQUIPMENT WITH DECREASE IN CONSUMPTION OF COMBUSTION PRODUCTS
}

O.I. Брунеткін, С.О. Горбань. Оптимізація тепловіддачі теплообмінних поверхонь котельного обладнання при зменшенні витрати продуктів згоряння. Розглянута можливість інтенсифікації тепловіддачі при зменшенні витрати продуктів згоряння при заданому тепловиділенні. Така ситуація може виникати під час використання в котельному обладнанні, яке розраховане на спалювання метану і яке має відповідну геометрію теплообмінних поверхонь, альтернативних (несертифікованих) горючих газів. Оцінювання виконано на прикладі використання етилену. Пропонується компенсувати зменшення кількості продуктів згоряння за рахунок використання рециркуляції димових газів. Розглянуто дві можливих точки їх подачі: в топку котла та на вхід в конвективні поверхні нагріву. Оцінена ефективність і проведено порівнювання цих варіантів.

Ключові слова: несертифіковане паливо, інтенсифікація тепловіддачі,рециркуляція димових газів

O.I. Brunetkin, S.O. Gorban. Heat transfer optimization of heat exchange surfaces of boiler equipment with decrease in consumption of combustion products. The possibility of intensifying of heat transfer process with decrease of consumption of combustion products for a given heat release is considered. Such situation can occur when alternative (uncertified) combustible gases are used in boiler equipment designed for methane burning and having certain geometry of the heat exchange surfaces. The evaluation was based on the use of ethylene. It is proposed to compensate the decrease of the combustion products due to the recirculation of flue gases. Two possible points of their supply were considered: in the furnace and to the entrance of the convective heating surfaces. The effectiveness was evaluated and a comparison of these options was made.

Keywords: uncertified fuel, heat transfer intensification, flue gas recirculation

Introduction. The use of uncertified fuel instead of fuel, for which energy equipment is designed, allows saving material resources. At the same time, the use of such fuel in existing energy equipment leads to complications, both in economic and environmental terms.

In the case of fuel with a higher calorific value, there are no problems with the relieving capacity of the equipment. But in the number of cases, for a given heat load the volume of combustion products and their velocity through the heat exchange surfaces can be smaller than the volume and velocity at the calculated standard conditions. As a consequence this reduces the heat transfer in the convective heat transfer surfaces.

One way to increase the coefficient of convective heat transfer can be increasing the volumetric flow of combustion products through convective heating surfaces by organizing the recirculation of flue gases.

Analysis of literary data and statement of the problem. Because of a rise of the cost of production and transportation of traditional energy carriers, interest to the use of alternative fuels increases. But the use of this fuel leads to certain problems, a number of works have been devoted to solving these

DOI: .

(c) 2017 The Authors. This is an open access article under the CC BY license (http://creativecommons.org/licenses/by/4.0/). 
problems. In [1], the method for determining the composition of fuel in the process of its combustion, in order to adjust the equipment for efficient burning of variable composition fuel, is proposed. But, even having determined the fuel composition and tuning the equipment for fuel combustion in a stoichiometric ratio with the oxidant, there still remains the problem of limited geometry of the furnaces of existing equipment, often designed for burning methane. And in the case of fuel combustion with a lower calorific value than methane, the solution is given in [1] using the operation of several boilers for a common steam pipe, but at burning fuel with a higher calorific value there remains the problem of loss of a significant part of the heat due to a decrease in the volume and velocity of the flue gases. The step in solving this problem was made in [2], where the range of convective heat transfer coefficient $\alpha_{k}$ was estimated with a decrease in the volume flow of combustion products.

For example, let us consider the stoichiometric combustion of methane and ethylene in air. To simplify the calculations, we take the ratio of oxygen and nitrogen in the air as 1:4. We will take into account that the heat of combustion of methane and ethylene is respectively equal to $35.83 \mathrm{MJ} / \mathrm{m}^{3}$ and $59.08 \mathrm{MJ} / \mathrm{m}^{3}$. In this case:

For one mole of methane

$$
\mathrm{CH}_{4}+2 \mathrm{O}_{2}+8 \mathrm{~N}_{2} \rightarrow \mathrm{CO}_{2}+2 \mathrm{H}_{2} \mathrm{O}+8 \mathrm{~N}_{2}
$$

For one mole of ethylene

$$
\mathrm{C}_{2} \mathrm{H}_{4}+3 \mathrm{O}_{2}+12 \mathrm{~N}_{2} \rightarrow 2 \mathrm{CO}_{2}+2 \mathrm{H}_{2} \mathrm{O}+12 \mathrm{~N}_{2}
$$

When providing equal heat release during combustion of methane and ethylene, last equation can be written the following way:

$$
0.6 \mathrm{C}_{2} \mathrm{H}_{4}+1.8 \mathrm{O}_{2}+7.2 \mathrm{~N}_{2} \rightarrow 1.2 \mathrm{CO}_{2}+1.2 \mathrm{H}_{2} \mathrm{O}+7.2 \mathrm{~N}_{2}
$$

Comparison of these equations shows that, with the same heat release, 11 moles of flue gas during combustion of methane corresponds to 9.6 moles when ethylene is burned. The situation is further accentuated when carbon monoxide or hydrogen is used as a combustible.

Purpose of the study. The change in fuel consumption will affect the consumption of gaseous products and the dynamics of heat exchange processes inside the furnaces and combustion chambers of heat and power equipment. When using traditional fuel, its costs and the parameters of the combustion products may change. These changes are limited and determined by changing the load. In the case of use of alternative fuels, changes can occur in a wider range of parameters. They are determined not only by changing the load but also by changing the fuel property, as well as joint action of these perturbations. And change of the fuel composition can occur more often than load changes. The role of equipment control increases in transient regimes in order to obtain energy with specified characteristics (energy quality).

Since the velocity and temperature of the flue gases have the greatest effect on the change in the convective heat transfer coefficient [2], in order to maintain these parameters at a constant level it is reasonable to consider possibility of using flue gas recirculation system. With the help of two smoke exhausters system, it is possible to maintain velocity of the flue gases at a given level, hence also parameters of convective heat transfer. But the use of flue gas recirculation also leads to a decrease of temperature in the boiler furnace, since the flue gases have much lower temperature.

The aim of the study is estimation of the influence of flue gas recirculation on heat and mass exchange inside power equipment, as well as analysis of the feasibility of using flue gas recirculation to maintain optimal heat transfer parameters.

Statement of the basic material. Due to the possibility of reducing the consumption of flue gases when using an alternative fuel with a higher calorific value, even under the condition of combustion with a stoichiometric ratio, heat release in convective surfaces of the boiler unit is reduced; this is due to a decrease of the velocity of flue gases and, as a consequence, a decrease of the coefficient of convective heat transfer.

As indicated in [2], the coefficient of convective heat transfer depends on a large extent on the velocity (which characterizes the Reynolds criterion), and the temperature of the flue gases.

$$
\alpha_{k}=C \cdot \operatorname{Re}^{\eta_{1}} \cdot \operatorname{Pr}^{\eta_{2}},
$$

where Re is the Reynolds criterion; Pr is Prandtl criterion. 
In order to compensate the reduction in the volumetric flow rate of combustion products at burning fuel with a higher calorific value, we will consider the advisability of using recirculation of flue gases to maintain the constancy of optimum parameters of convective heat transfer.

When organizing the process of recirculation of flue gases, it is possible to supply them to the boiler furnace or to the entrance of the convective heating surfaces.

First let us study the option of supplying flue gases directly to the furnace of the boiler. Since the temperature of the flue gases is in the range of $500 . .700^{\circ} \mathrm{K}$, supplying them directly into the furnace of the boiler will cause a drop of the temperature in the furnace.

To estimate the effect of flue gas recirculation on heat release in convective and radiation surfaces, we calculate the heat release from burning ethylene without recirculation and then compare with the results of calculating of the heat release using flue gas recirculation.

Let us consider the heat release in convective heating surfaces [3]

$$
Q_{k}=\alpha_{k} \cdot \Delta T \cdot F_{k},
$$

Table 1 where $Q_{k}$ is the amount of heat perceived by

The heat transfer coefficient and the specific amount of heat delivered by the flue gases to the convective surfaces when flue gases are fed into the boiler furnace

\begin{tabular}{c|c|c}
\hline Flue gas source & $\alpha_{k}, \mathrm{~W} /\left(\mathrm{m}^{2} \cdot \mathrm{K}\right)$ & $Q_{k}, \mathrm{~kJ} / \mathrm{m}^{2}$ \\
\hline Ethylene & 37.7 & 51.7 \\
\hline Ethylene + recirculation & 63.6 & 68.3 \\
\hline
\end{tabular}

convective heat surfaces (Table 1 ), $\alpha_{k}$ is the convective heat transfer coefficient (Table 1), $\Delta T$ is the temperature difference, and $F_{k}$ is the surface area of the heating.

From the results of the calculation it can be established that when the flue gas is fed into the boiler furnace by recirculation, to compensate the volume and thus the velocity of the flue gases, the convective heat transfer coefficient increases by $68 \%$, which leads to increase of heat release by $33 \%$.

Let us consider the radiation heating surfaces under the same conditions [4]:

$$
Q_{p}=c_{0} \cdot\left(\frac{T_{1}^{4}}{100}-\frac{T_{2}^{4}}{100}\right) \cdot F_{p},
$$

where $Q_{p}$ is the amount of heat perceived by radiation

Table 2
Specific amount of heat perceived by radiation heating surfaces when flue gas is fed into the boiler furnace

\begin{tabular}{c|c}
\hline Flue gas source & $Q_{p}, \mathrm{~kJ} / \mathrm{m}^{2}$ \\
\hline Ethylene & 162.2 \\
\hline Ethylene + recirculation & 86.3 \\
\hline
\end{tabular}

heating surfaces (Table 2); $c_{0}$ is emissivity coefficient of the absolute black body; $\mathrm{T}_{1}$ is temperature in the furnace, $K ; T_{2}$ is temperature of the heat-sensing surface, $K ; F_{P}$ is area of radiation heating surface, $\mathrm{m}^{2}$.

From the results of the calculation it can be concluded that the heat release in the radiation surfaces decreased by $87 \%$, due to the temperature drop in the furnace from $2100^{\circ} \mathrm{K}$ to $1800^{\circ} \mathrm{K}$. However, taking into account the fact that in gas boilers the area of the convective heating surface is much larger than the radiation area (for example, in DKVR 20-13 boiler, the area of the radiation surface is $51 \mathrm{~m}^{2}$, and the convective surface is $357 \mathrm{~m}^{2}$ ), then by calculating the heat release considering the surface area, we obtain the following (Table 3).

$$
\begin{gathered}
\Delta Q_{P}=4.47-8.27=-3.8 \mathrm{MJ} \\
\Delta Q_{K}=24.85-18.84=6.018 \mathrm{MJ}
\end{gathered}
$$

From the above data it follows that the increase in heat release in convective surfaces almost 2 times covers the loss in the radiation part.

In addition, since the temperature in the furnace of the boiler is reduced, the concentration of nitrogen oxides in the flue gases is correspondingly reduced. 
Let us consider the effect of the organiza-

Table 3 tion of flue gases recirculation by supplying them to the entrance of the convective heat exchange surfaces.

Since combustion products will not enter the furnace, the use of flue gas recirculation will not affect the heat release in the radiant surfaces of heat exchange, hence we consider the heat release in convective heating surfaces.

The temperature of the combustion products at the outlet from the furnace is in the range of $1400 \ldots 1300^{\circ} \mathrm{K}$. After mixing the combustion products with flue gases at a temperature of $700 \ldots 500^{\circ} \mathrm{K}$, flue gases with a temperature of $1200 \ldots 1100^{\circ} \mathrm{K}$ come to the entrance of the convective surfaces. Taking into account the accepted value of the convective heat transfer coefficient $\alpha_{k}=63.6$ $\mathrm{W} /\left(\mathrm{m}^{2} \cdot \mathrm{K}\right)$, the convective component of the specific heat transfer will be the following:

$$
Q_{k}=76.4 Q_{K}, \mathrm{~kJ} / \mathrm{m}^{2} \text {. }
$$

Since the volume flow of flue gases remained at the same level that when organizing the supply of flue gases directly to the furnace of the boiler, therefore, $\alpha_{k}$ has not changed. The increase in heat release provided an increase of the temperature difference.

In order to compare two methods of supply of flue gases we calculate the heat release in the heating surfaces of the boiler DKVR 20-13 (Table 4).

In comparison with the supply of flue

Radiation and convective heat transfer components when flue gases are fed into the boiler furnace

\begin{tabular}{c|c|c}
\hline Flue gas source & $Q_{p}, \mathrm{MJ}$ & $Q_{k}, \mathrm{MJ}$ \\
\hline Ethylene & 8.27 & 18.84 \\
\hline Ethylene + recirculation & 4.47 & 24.85 \\
\hline
\end{tabular}
gases directly to the furnace of the boiler, due to the temperature in the boiler furnace, when flue gas is fed to the entrance of the convective surfaces, the radiation heat exchange remains at the same level as before the use of recirculation, besides, due to the increase in the temperature difference, the heat emission increases in the convective heat surfaces.

Analysis of the results. Based on the results of calculations, in order to maintain flue gas consumption at a level close to that for which energy equipment was calculated, the use of flue gas recirculation allows to maintain the parameters of heat and mass transfer of convective heating surfaces at the calculated level, and as a result to improve the heat reception of convective heating surfaces.

When organizing the supply of flue gases directly to the furnace of the boiler, due to the temperature fall in the furnace, the heat reception of the radiation surfaces decreases, although the increase in heat release in convective surfaces allows us to cover these losses. In addition, because of the temperature drop in the furnace, the concentration of nitric oxide in the flue gases is reduced, which in turn increases the efficiency of burning uncertified fuels in terms of ecology.

In turn, the organization of supply of flue gases to the entrance of the convective heating surfaces allows preserving the parameters of radiative heat transfer, and also, due to the increase in the temperature difference in the convective part, it makes it possible to increase the total heat release by 22\% in comparison with the organization of supply of flue gases to the furnace of the boiler. But, given that the temperature in the furnace remains at the same level as before the use of recirculation, this way of organizing recycling loses its effectiveness in an ecological sense, as the concentration of nitrogen oxides remains at the same level as before recycling.

Conclusions. In the course of the study, the value of the decrease in the heat transfer of combustion products was determined using alternative gaseous fuels instead of the boiler equipment certified fuel for fixed geometry and the specified heat content of the fuel. 
The method is proposed for increasing heat transfer by increasing the flow of flue gases through heat exchange surfaces when organizing the recirculation of the required amount of flue gases.

Two options of the introduction points of recirculating flue gases are considered. As a result of the calculations it was determined that the supply of flue gases to the entrance of the convective surfaces allows increasing the heat reception of the convective surfaces without negative influence on the parameters of radiative heat transfer. In the case with the supply of flue gases directly into the furnace of the boiler, due to the temperature fall in the furnace, the heat reception of the radiation surfaces deteriorates.

\section{Література}

1. Maksimov M.V., Lozhechnikov V.F., Dobrovolskaya T.S., Bondarenko A.V. Mathematical model of burning non-certified fuels. East-European Journal of Advanced Technologies. 2014. №2/8 (68). P. 44-51.

2. Brunetkin O.I., Gusak A.V. Determination of the range of change of the convective heat transfer coefficient during the burning of alternative types of gaseous fuel. Proceedings of the Odessa Polytechnic University, 2015. №2(46). P. 79-84.

3. Thermal calculation of boilers (normative method). 3rd ed., Revised and additional. St. Petersburg: NPO CKTI, 1998. 256 p.

4. Сидельковский Л.Н., Юренев В.Н. Котельные установки промышленных предприятий. Москва: Энергоатомиздат, 1988. $528 \mathrm{c}$.

\section{References}

1. Maksimov, M.V., Lozhechnikov, V.F., Dobrovolskaya, T.S., \& Bondarenko, A.V. (2014). Mathematical model of burning non-certified fuels. East-European Journal of Advanced Technologie, 2/8 (68), 44-51.

2. Brunetkin, O.I., \& Gusak, A.V. (2015). Determination of the range of change of the convective heat transfer coefficient during the burning of alternative types of gaseous fuel. Proceedings of the Odessa Polytechnic University, 2(46), 79-84.

3. Thermal calculation of boilers (normative method). Revised and additional. (3rd ed.). (1998). St. Petersburg: NPO CKTI.

4. Sidelkovsky, L.N., \& Yurenev, V.N. (1988). Heat exchange in the furnace. Moskva: Energoatomizdat. 